\title{
Supporting Information: Suppression of DNA Polymerase $\beta$ Activity is Synthetically Lethal in BRCA1-Deficient Cells
}

Shelby Yuhasa, Alok Mishrab,c, Theodore L. DeWeese ${ }^{b, c}$ and Marc M. Greenberg ${ }^{* a}$

aDepartment of Chemistry, Johns Hopkins University, 3400 N. Charles St., Baltimore, MD 21218 bDepartment of Radiation Oncology and Molecular Radiation Sciences, Johns Hopkins University School of Medicine, 401 N. Broadway, Baltimore, MD 21231.

cSidney Kimmel Comprehensive Cancer Center, Johns Hopkins University School of Medicine, Baltimore, MD 21231

*Corresponding author: Marc M. Greenberg

Contents:

1. General Methods (S2)

2. Experimental Methods (S3-S7)

3. Figure S1. Western blot analysis of Pol $\beta$ knock down in UWB1.289 cells. (S7)

4. Figure S2. Representative plate of clonogenic survival assay (S7).

5. References (S8) 


\section{General Methods}

Dulbecco's Modified Eagle Medium (DMEM) with high glucose, RPMI 1640 Medium with GlutaMAX supplement, Opti-MEM reduced serum medium, and insulin were obtained from ThermoFisher. Human Mammary Epithelial Cell Growth Medium (MEGM) was purchased from Sigma-Aldrich. Antibiotic antimycotic solution (penicillin, streptomycin, and amphotericin B), and fetal bovine serum (FBS) were obtained from MilliporeSigma. PBS buffer was obtained from Quality Biological. Trypsin-EDTA $(0.25 \%)$ solution was purchased from ThermoFisher. Pre-cast 4-20\% SDS-PAGE, Precision Plus Protein WesternC standard, Western blot kit, and StrepTactinHRP conjugate were from BioRad. NP-40 was obtained from Sigma Aldrich. Lipofectamine RNAiMAX was purchased from ThermoFisher. siRNAs (siGENOME RISC-Free Control, D001220-01; siGENOME Human POLB siRNA, D-005164-04) were purchased from Horizon Discoveries. Recombinant Anti-DNA Polymerase beta antibody (ab175197) was purchased from Abcam. Cells were counted using a BioRad TC20 cell counter. Western blots were carried out using a BioRad Trans-Blot Turbo Transfer system. Ponceau red stain was prepared with ponceau $S$ tetrasodium salt $\left(0.1 \%\right.$, Sigma Aldrich) and acetic acid $(5 \%)$ in distilled $\mathrm{H}_{2} \mathrm{O}$. Pierce ECL Western Blotting Substrate developing reagents were acquired from ThermoFisher. Western blots were visualized using a Typhoon 9410 equipped with chemiluminescence imaging at the Integrated Imaging Center at Johns Hopkins University.

UWB1.289 and UWB1.289 + BRCA1 cells were provided by Prof. Peter Glazer, Yale University. Mouse embryonic fibroblasts (Pol $\beta$ WT and Pol $\beta-/-)$ were generous gifts from Dr. Sam Wilson, NIH. MDA-MB-436 cells (homozygous mutated BRCA1, Basal B adenocarcinoma breast cancer cell line) were obtained from Prof. Theodore DeWeese, Johns Hopkins University.

Pro-inhibitor (pro-1) was previously prepared. ${ }^{1}$ Solutions (100X) of pro-1 and Olaparib were prepared in $50 \%$ MeCN in $\mathrm{H}_{2} \mathrm{O}$. 


\section{Growth conditions for cell lines}

UWB1.289 (BRCA1 -/-) and UWB1.289 + BRCA1 cells were grown in a 1:1 mixture of RPMI-1640 and MEGM media supplemented with $3 \% \mathrm{FBS}$ at $37{ }^{\circ} \mathrm{C}$ in a $5 \% \mathrm{CO}_{2}$ humidified incubator. The media bottle was covered with aluminum foil when not in use and aliquots (50-100 $\mathrm{mL}$ ) were removed and warmed in a $37{ }^{\circ} \mathrm{C}$ water bath as needed. ${ }^{2}$

Mouse embryonic fibroblast cells were grown in DMEM with high glucose supplemented with $9 \% \mathrm{FBS}$ at $34{ }^{\circ} \mathrm{C}$ in a $10 \% \mathrm{CO}_{2}$ humidified incubator. ${ }^{3,4}$

MCF-7 and MDA-MB-436 cells were grown in RPMI 1640 Medium with GlutaMAX supplement, supplemented with $0.05 \%$ insulin, $9 \%$ FBS, and $1 \%$ antibiotic antimycotic solution at $37^{\circ} \mathrm{C}$ in a $5 \% \mathrm{CO}_{2}$ humidified incubator. ${ }^{5,6}$

\section{Clonogenic assay for cell survival}

Approximately $2 \times 10^{5}$ cells were plated in each well of a 6 -well culture plate (well size; 35 $\mathrm{mm} \times 18 \mathrm{~mm}$ ) in medium $(1 \mathrm{~mL})$ and kept in a humidified incubator at $37^{\circ} \mathrm{C}$ with $5 \% \mathrm{CO}_{2}$. After incubating overnight, cells were subjected to either the vector $\left(50 \% \mathrm{MeCN}\right.$ in $\left.\mathrm{H}_{2} \mathrm{O}, 10 \mu \mathrm{L}\right)$ or treatment (100X pro-1, $10 \mu \mathrm{L}$ or 100X Olaparib, $10 \mu \mathrm{L})$. After treatment, the medium was removed, and the cells were washed with 1 X PBS $(2 \times 1 \mathrm{~mL})$. The cells were trypsinized with $0.25 \%$ TrypsinEDTA $\left(0.5 \mathrm{~mL}\right.$ in each well, 5 min incubation at $\left.37^{\circ} \mathrm{C}\right)$, washed with the appropriate media supplemented with FBS for the corresponding cell line $(1 \mathrm{~mL})$ to quench the trypsin cleavage, and spun down (3,000 RCF x $5 \mathrm{~min})$. The medium was removed, and the cells were resuspended in fresh media $(10 \mathrm{~mL})$. The single cell suspensions were collected and counted using a TC20 Automated Cell Counter (BIO-RAD).

Stock solutions of single cell suspensions were prepared for all untreated and treated cells. For example, 100 cells $/ \mathrm{mL}$ stock solution of untreated cells were prepared; $500 \mathrm{cells} / \mathrm{mL}$ stock solutions of treated cells were prepared. The concentration of stock solution for each sample was chosen based on expected toxicity of the treatment (i.e. higher cell counts for more toxic 
conditions). The appropriate number of cells for each experiment were seeded in each well of a 6-well plate (well size; $35 \mathrm{~mm} \times 18 \mathrm{~mm}$ ) in $3 \mathrm{~mL}$ of medium. The cells were grown in a humidified incubator at $37^{\circ} \mathrm{C}$ with $5 \% \mathrm{CO}_{2}$ for 14 days (21 days for UWB1.289 cells). No significant change in media volume was observed after two-three weeks due to evaporation. After 14 days, the growth medium was discarded, and the attached cells were treated with $0.2 \% \mathrm{w} / \mathrm{v}$ aqueous crystal violet solution $(1 \mathrm{~mL})$. The excess dye was removed by washing with water twice. The plates were dried and scanned with an HP Scanjet 3970 and colonies were counted using ImageJ (FIJI, free download from $\mathrm{NIH}$ ).

Plating efficiencies (PE) and survival fractions (SF) were calculated as follows: PE = number of colonies/number of cells seeded; SF $=\mathrm{PE} / \mathrm{PE}_{\text {control. }}$

\section{Cell viability assays for mouse embryonic fibroblasts ${ }^{3,4}$}

Mouse embryonic fibroblasts (Pol $\beta$ WT, Pol $\beta-/-$ ) were seeded at a density of $\sim 3 \times 10^{5}$ cells/well in 6-well dishes. The following day, cells were exposed to pro-1 $(0,5,25 \mu \mathrm{M})$ or Olaparib $(0,0.5,1 \mu \mathrm{M})$ in medium $(1 \mathrm{~mL})$ for $1 \mathrm{~h}$. Control wells were treated with an equal volume of vector (50\% MeCN in $\left.\mathrm{H}_{2} \mathrm{O}\right)$. Cells were washed with $1 \mathrm{X}$ PBS and fresh medium was added. Dishes were incubated at $34{ }^{\circ} \mathrm{C}$ in a $10 \% \mathrm{CO}_{2}$ incubator, until untreated control cells were $\sim 80 \%$ confluent, which was 5 days. Cells (triplicate wells for each treatment concentration were counted by a cell lysis procedure (described previously in the clonogenic assay procedure), and the results were expressed as the surviving fraction of cells in drug-treated wells relative to control wells.

\section{Pol $\beta$ knock down by siRNA ${ }^{7}$}

UWB1.289 cells $\left(6 \times 10^{6}\right)$ were seeded with RPMI 1640/MEGM medium (10 mL) into a $100 \mathrm{~mm}$ plate prior to transfection so cells would be adherent and $\sim 80 \%$ confluent on the first day of transfection, which was determined by manual inspection. Transfection was completed as follows: 
1. Lipofectamine RNAiMAX (60 $\mu \mathrm{L})$ was diluted in Opti-MEM reduced serum medium to 1 $\mathrm{mL}$.

2. In a separate tube, siRNA (either siNT or siPol $\beta, 10 \mu \mathrm{M}, 60 \mu \mathrm{L}, 600$ pmol) was diluted in Opti-MEM $(500 \mu \mathrm{L})$.

3. The Lipofectamine solution was split $(2 \times 500 \mu \mathrm{L}$ aliquots $)$ and mixed with either siNT or siPol $\beta$ solution to form the lipid-RNA complex at $25^{\circ} \mathrm{C}$ for $5 \mathrm{~min}$.

4. The RPMI 1640/MEGM medium was removed and replaced with Opti-MEM medium (9 $\mathrm{mL})$. After $5 \mathrm{~min}$ incubation, the lipid-RNA solution $(1 \mathrm{~mL})$ was added to the cells. Cells were incubated at $37^{\circ} \mathrm{C}$ in a $5 \% \mathrm{CO}_{2}$ humidified incubator.

The following day, steps 1-3 were repeated. and the resulting $2 \times 500 \mu \mathrm{L}$ solutions were added to the existing cells that had been incubating at $37^{\circ} \mathrm{C}, 5 \% \mathrm{CO}_{2}$ for $24 \mathrm{~h}$. Transfected cells were allowed to incubate for an additional $48 \mathrm{~h}$ at $37^{\circ} \mathrm{C}, 5 \% \mathrm{CO}_{2}$ after the second addition of siRNA. After a total of $72 \mathrm{~h}$, cells were harvested (described previously in the clonogenic assay procedure) and reseeded into 6-well plates for a clonogenic assay (described previously). A portion of the transfected cells $\left(2 \times 10^{6}\right)$ were used to determine knock down efficiency by Western blot.

\section{Western Blot Analysis}

Cells were trypsinized with $0.25 \mathrm{w} / \mathrm{v}$ Trypsin-EDTA $(1 \mathrm{~mL}$ in each plate $(100 \mathrm{~mm}), 5 \mathrm{~min}$ incubation at $37^{\circ} \mathrm{C}$ ), washed with RPMI 1640/MEGM-FBS $(10 \mathrm{~mL}$ ) to quench the trypsin cleavage, and spun down (3,000 RCF x 5 min). The medium was removed, and cells were washed with cold 1X PBS buffer and spun down $\left(2 \times 3000 \mathrm{RCF}, 4{ }^{\circ} \mathrm{C}, 5 \mathrm{~min}\right)$ twice. The cell pellet was resuspended in nuclear fractionation lysis buffer $\left(1 \mathrm{~mL} / 10^{7}\right.$ cells; $20 \mathrm{mM} \mathrm{HEPES} \mathrm{pH} \mathrm{7.5,} 0.25 \mathrm{M}$ sucrose, $1 \mathrm{mM}$ PMSF, $3 \mathrm{mM} \mathrm{MgCl} 2,0.2 \% \mathrm{NP}-40$, with protease inhibitor). Cells were incubated in lysis buffer on ice for 15 min with occasional mixing by inverting the tube back and forth, after which they were spun down $\left(3,000 \mathrm{RCF}, 4{ }^{\circ} \mathrm{C}, 15 \mathrm{~min}\right)$. The supernatant was discarded. The cell 
pellet was resuspended and incubated in RIPA lysis buffer $\left(0.5 \mathrm{~mL} / 10^{7}\right.$ cells; $10 \mathrm{mM}$ Tris $\mathrm{pH} 8.0$, $1 \mathrm{mM}$ EDTA, $0.5 \mathrm{mM}$ EGTA, $1 \%$ sodium deoxycholate, $0.1 \%$ SDS, $140 \mathrm{mM} \mathrm{NaCl}$ ) on ice for 20 min with occasional mixing by inverting the tube back and forth. The cells were spun down $(16,000$ $\mathrm{RCF}, 4^{\circ} \mathrm{C}, 10 \mathrm{~min}$ ). The supernatant (cell lysate) was transferred to a new tube. The concentration of proteins in cell lysate were determined by Bradford assay. The cell lysate was split into two sets and each portion (20 $\mu \mathrm{g}$ of protein) along with Precision Plus Protein WesternC standard (5 $\mu \mathrm{L}$ ) protein ladder was loaded separately onto precast $4-20 \%$ SDS-PAGE to visualize the amount of Pol $\beta$ present or an internal standard (i.e. $\alpha-\mathrm{H} 3$ ). The $\mathrm{H} 3$ antibody was used to quantify the relative amounts of $\mathrm{H} 3$ in the control and knock down cells to account for any variation in protein(s) loaded onto the gel. The relative amounts of $\mathrm{H} 3$ were used to normalize the knock down of Pol $\beta$ expression observed.

Proteins were transferred from the gel to a nitrocellulose membrane (25 V, $1 \mathrm{~A}, 30 \mathrm{~min})$ using a BioRad Trans-Blot Turbo Transfer system. The membrane was stained with ponceau red stain for 5 min then washed with $\mathrm{H}_{2} \mathrm{O}$ until the background was removed. The membrane was cut and separated so one set of samples could be incubated with the Pol $\beta$ antibody and the other set with $\mathrm{H} 3$ antibody. The membranes were blocked with 3\% BSA in 1X Tris-buffered saline tween (TBST; $20 \mathrm{mM}$ Tris, $150 \mathrm{mM} \mathrm{NaCl}, 0.1 \%$ Tween) buffer for $30 \mathrm{~min}$ at $25^{\circ} \mathrm{C}$ while shaking. The membranes were incubated with the primary antibody solution $(5 \mathrm{~mL}$, Recombinant Anti-DNA Polymerase beta antibody, 1:1000 Ab in 3\% BSA in TBST; Recombinant Anti-Histone H3 antibody, 1:1000 Ab in TBST) at $4{ }^{\circ} \mathrm{C}$ overnight. The membranes were washed $(3 \times 5$ min TBST, $5 \mathrm{~mL}$ ). The membranes were incubated with secondary antibody solution (Rabbit anti-goat antibody, $5 \mathrm{~mL}, 1: 5000 \mathrm{Ab}$ in 3\% BSA in TBST with StrepTactin-HRP conjugate, $0.5 \mu \mathrm{L}$ ) at $25^{\circ} \mathrm{C}$ for $1 \mathrm{~h}$. The membranes were washed ( $3 \times 5 \mathrm{~min}$ TBST, $5 \mathrm{~mL}$ ). Membranes were kept in Trisbuffered saline (TBS; $20 \mathrm{mM}$ Tris, $150 \mathrm{mM} \mathrm{NaCl}$ ) buffer until incubated with developing reagent 
(5 mL) for 5 min and scanned using a Typhoon 9410 equipped with chemiluminescence imaging (Medium quality, 600 PVT, 200 pixels).
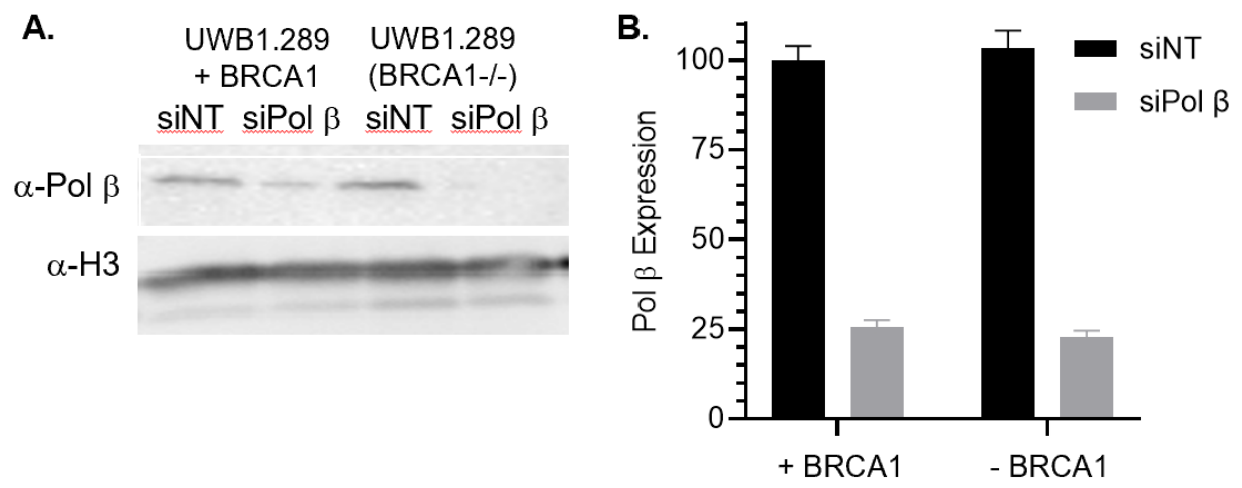

Figure S1. Western blot analysis of Pol $\beta$ knock down in UWB1.289 cells. (A) Western blot and (B) Relative levels of Pol $\beta$ expression in transfected cells. Data are avg \pm std. dev (three replicates).

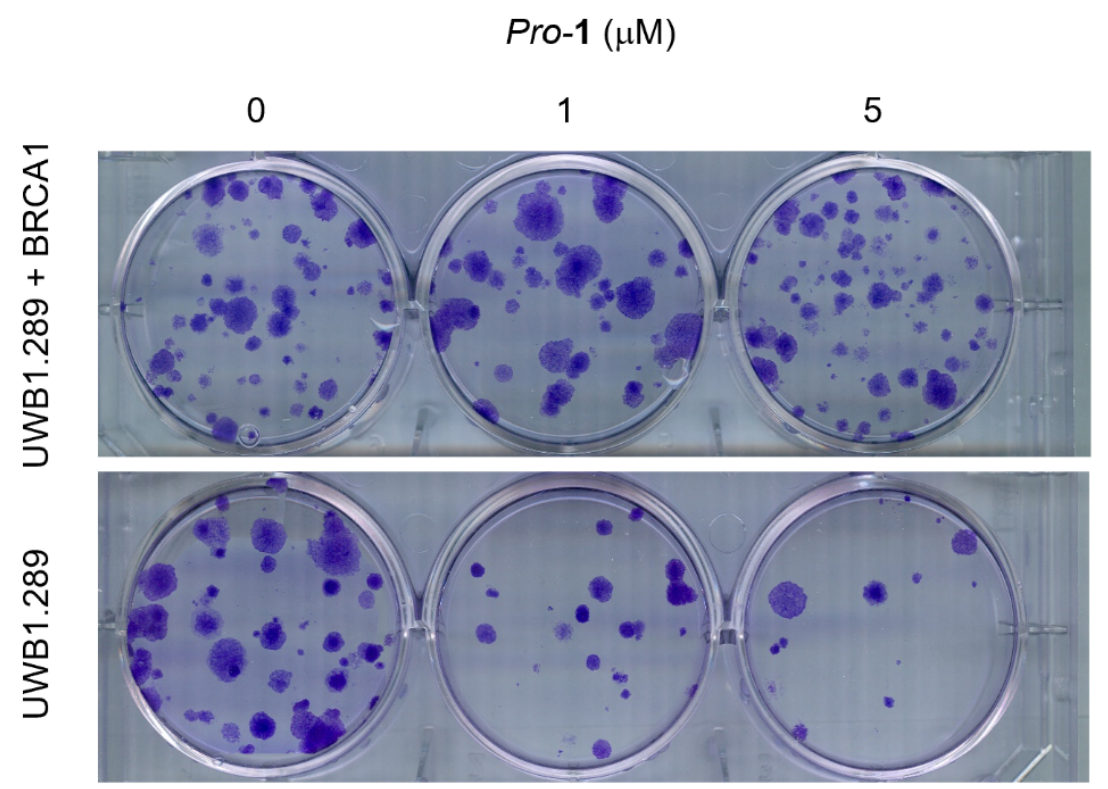

Figure S2. Representative plate of clonogenic survival assay (single replicate pictured). 


\section{References}

(1) Yuhas, S. C., Laverty, D. J., Lee, H., and Greenberg, M. M. (2021) Selective Inhibition of DNA Polymerase $\beta$ by a Covalent Inhibitor, J. Am. Chem. Soc. 143, 8099-8107.

(2) Chen, S.-H., and Yu, X. (2019) Targeting DePARylation Selectively Suppresses DNA Repair-Defective and PARP Inhibitor-Resistant Malignancies, Science 5, eaav4340.

(3) Braithwaite, E. K., Kedar, P. S., Stumpo, D. J., Bertocci, B., Freedman, J. H., Samson, L. D., and Wilson, S. H. (2010) DNA Polymerases $\beta$ and $\lambda$ Mediate Overlapping and Independent Roles in Base Excision Repair in Mouse Embryonic Fibroblasts, PLoS ONE 5, e12229.

(4) Hu, H. Y., Horton, J. K., Gryk, M. R., Prasad, R., Naron, J. M., Sun, D. A., Hecht, S. M., Wilson, S. H., and Mullen, G. P. (2004) Identification of Small Molecule Synthetic Inhibitors of DNA Polymerase b by NMR Chemical Shift Mapping, J. Biol. Chem. 279, 39736-39744.

(5) Amin, O., Beauchamp, M.-C., Nader, P., Laskov, I., Iqbal, S., Philip, C.-A., Yasmeen, A., and Gotlieb, W. (2015) Suppression of Homologous Recombination by Insulin-like Growth Factor-1 Inhibition Sensitizes Cancer Cells to PARP Inhibitors, BMC Cancer 15, 817-826.

(6) Song, Z., Zhang, X., Lin, Y., Wei, Y., Liang, S., and Dong, C. (2019) LINC01133 Inhibits Breast Cancer Invasion and Metastasis by Negatively Regulating SOX4 Expression through EZH2, Jounral Cell. Mol. Med. 23, 7554-7565.

(7) Ray, S., Breuer, G., DeVeaux, M., Zelterman, D., Bindra, R., and Sweasy, J. B. (2018) DNA Polymerase Beta Participates in DNA End-Joining, Nucleic Acids Res. 46, 242-255. 